\title{
Parlamentos Supranacionais na Europa e na América Latina: Entre o Fortalecimento e a Irrelevância**
}

Andrés Malamud** e Luís de Sousa***

\section{Introdução}

\begin{abstract}
A moderna instituição parlamentar nasceu na Inglaterra do século XVII, como instrumento de controle dos poderes monárquicos por parte de uma burguesia ascendente. Não foi um acontecimento singular e isolado na história política européia, mas o resultado de um
\end{abstract}

\footnotetext{
* Agradecemos a Daniel Bach, Helena Carreiras, Anne-Sophie Claeys-Nivet, Olivier Costa, Helge Hveem e Laurence Whitehead pelos comentários a versões prévias deste artigo. Luís de Sousa também agradece à Fundação Calouste Gulbenkian por ter financiado parte deste projeto no âmbito do Programa Gulbenkian de Estímulo à Investigação 2003. Versões anteriores foram apresentadas no Fifth Pan-European International Relations Conference (SGIR-ECPR), em Aia, Holanda, 9-11 de setembro de 2004; no XXV Latin American Studies Association Congress (LASA 2004), Las Vegas, Nevada, 7-9 de outubro de 2004; e no First Global International Studies Conference, World International Studies Committee (WISC), Estambul, 24-27 de agosto de 2005. Artigo recebido em dezembro de 2004 e aceito para publicação em agosto de 2005.

** Investigador auxiliar no Centro de Investigação e Estudos de Sociologia (CIES-ISCTE) de Lisboa e professor auxiliar de Ciência Política na Universidade de Buenos Aires.

*** Investigador auxiliar no Centro de Investigação e Estudos de Sociologia (CIES-ISCTE) de Lisboa.
}

CONTEXTO INTERNACIONAL Rio de Janeiro, vol. 27, no 2, julho/dezembro 2005, pp. 369-409. 
processo gradual de desenvolvimento institucional para o qual contribuíram experiências da Antiguidade, tais como a assembléia geral de archons e o areopagus da antiga Grécia, o senado da República de Roma e os conselhos dos povos escandinavos. O Parlamento viria reclamar para si três competências ou poderes fundamentais, nos processos de governança: 1) a supremacia legislativa; 2) o poder último de decisão e de fiscalização sobre as políticas de tributação e de despesa pública; e 3) a possibilidade de intervir indiretamente no processo de decisão, quer por meio da impugnação da escolha de um ministro da coroa, quer pelo poder de votar a incapacitação do soberano. Este modelo de assembléia representativa seria, posteriormente, exportado para o continente americano, onde se consolidaria como órgão de soberania autônomo. Regressaria à Europa continental com a Revolução Francesa e seria, novamente, exportado para o resto do mundo, afirmando-se, finalmente, como $a$ instituição emblemática dos processos de deliberação política e legislativos na maioria dos Estados modernos.

Assembléias legislativas análogas tiveram também a sua difusão ao nível subnacional, em Estados (con)federados ou províncias autônomas que, posteriormente, constituíram-se em Estados federais. Se os Parlamentos subnacionais datam, pelo menos, do século XVIII, pois já se encontravam presentes em algumas colônias americanas quando foi proclamada a independência e jurada a Constituição, os Parlamentos supranacionais são criações recentes.

O primeiro Parlamento supranacional relevante foi o Parlamento Europeu. Na definição dada pelo Tratado de Roma de 1957, o Parlamento Europeu é "composto por representantes dos povos dos Estados reunidos na Comunidade". A legitimidade do Parlamento Europeu baseia-se no sufrágio direto e universal dos seus membros - desde 1979 - e a sua investidura tem uma duração de cinco anos. Outros

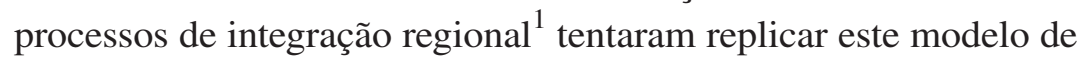
assembléia legislativa supranacional, sendo a América Latina a re- 
gião onde a experimentação ou mimetismo institucional teve maior repercussão. Em junho de 2004, a International Parlamentary Union, organização internacional que reúne de um modo associativo os vários Parlamentos nacionais a nível mundial, era composta por 140 membros nacionais e cinco associados, estes últimos de carácter regional/internacional: o Parlamento Andino, o Parlamento Centro-Americano, o Parlamento Europeu, o Parlamento Latino-Americano e a Assembléia Parlamentar do Conselho da Europa. Para além destes, a Comissão Parlamentar Conjunta do Mercosul representa também o embrião de uma instituição representativa supranacional e merece, por isso, um escrutínio mais atento.

Este desenvolvimento político e institucional levanta várias questões. A primeira é saber por que razão os líderes políticos optaram por estabelecer um Parlamento regional (Rittberger, 2003) quando o processo de integração era, substancialmente, uma iniciativa de cariz econômico. A segunda é estabelecer se os órgãos parlamentares regionais constituem Parlamentos propriamente ditos ou algo diferente. Finalmente, inquere-se por que razão os Parlamentos regionais se desenvolveram apenas em duas regiões do mundo, nomeadamente Europa e América Latina, e quais as diferenças observáveis entre os processos de integração regional nestas regiões. $\mathrm{O}$ artigo discute estas questões por meio da análise comparativa de cinco Parlamentos regionais, ditos supranacionais: todos aqueles anteriormente mencionados, menos a Assembléia Parlamentar do Conselho da Europa, porque se trata apenas de um órgão de deliberação coletiva e não de decisão, para o qual não se antevê nenhum novo desenvolvimento institucional que aponte em outra direção.

$\mathrm{O}$ artigo está dividido em cinco partes iniciais que incidem sobre cada um dos cinco Parlamentos regionais. Trata-se de uma breve análise da evolução histórica e política destes organismos, examinados na sua estrutura, competências e modo de funcionamento à luz de quatro funções parlamentares clássicas: representação (legitimiza- 
ção), legislação (processo de decisão), controle do Executivo e do aparelho do Estado (fiscalização) e formação de elites e liderança política (recrutamento e treino). A parte final do artigo apresenta um conjunto de conclusões comparativas.

\section{O Parlamento Europeu (PE)}

Quem olhar pela primeira vez o tecido institucional da Europa ficará surpreendido com a existência de vários arranjos institucionais que se sobrepõem, interagem e se articulam de modo a tornar a União Européia (UE) um modelo único de integração regional. Tendo em conta o nível de integração conseguido entre os vários membros e a extensão e intensidade das suas competências políticas, a UE é a estrutura organizacional central da Europa. Existe, contudo, uma série de organizações anteriores aos Tratados de Roma de 1957 que deram, cumulativamente, um contributo significativo para a singularidade do processo de integração europeu - ainda que limitado, menos abrangente e sem poder de decisão. Algumas delas sobreviveram ao processo de integração europeu proporcionado pelas comunidades dos Tratados de Roma, mas ficaram reduzidas a um papel deliberativo secundário e simbólico - como, por exemplo, o Conselho da Europa - ou foram, ultimamente, incorporadas pelas sucessivas revisões dos tratados - tal como aconteceu com a União da Europa Ocidental, incorporada na política européia de defesa mediante o Tratado de Maastricht ${ }^{2}$. Algumas destas organizações mantiveram a sua filiação e caráter europeu; outras, tais como a Organização para Cooperação e Desenvolvimento Econômico (OCDE), expandiram suas atividades para outros países e regiões além da Europa. Todavia, um dos elementos comuns mais salientes a estas organizações continua sendo a existência de Parlamentos ou assembléias de cariz regional (Quadro 1).

Poderiam ainda ser mencionadas outras iniciativas de carácter interparlamentar ou fóruns regionais, tais como: o Conselho Nórdico, que 
Parlamentos Supranacionais na Europa e na

América Latina: Entre o Fortalecimento...

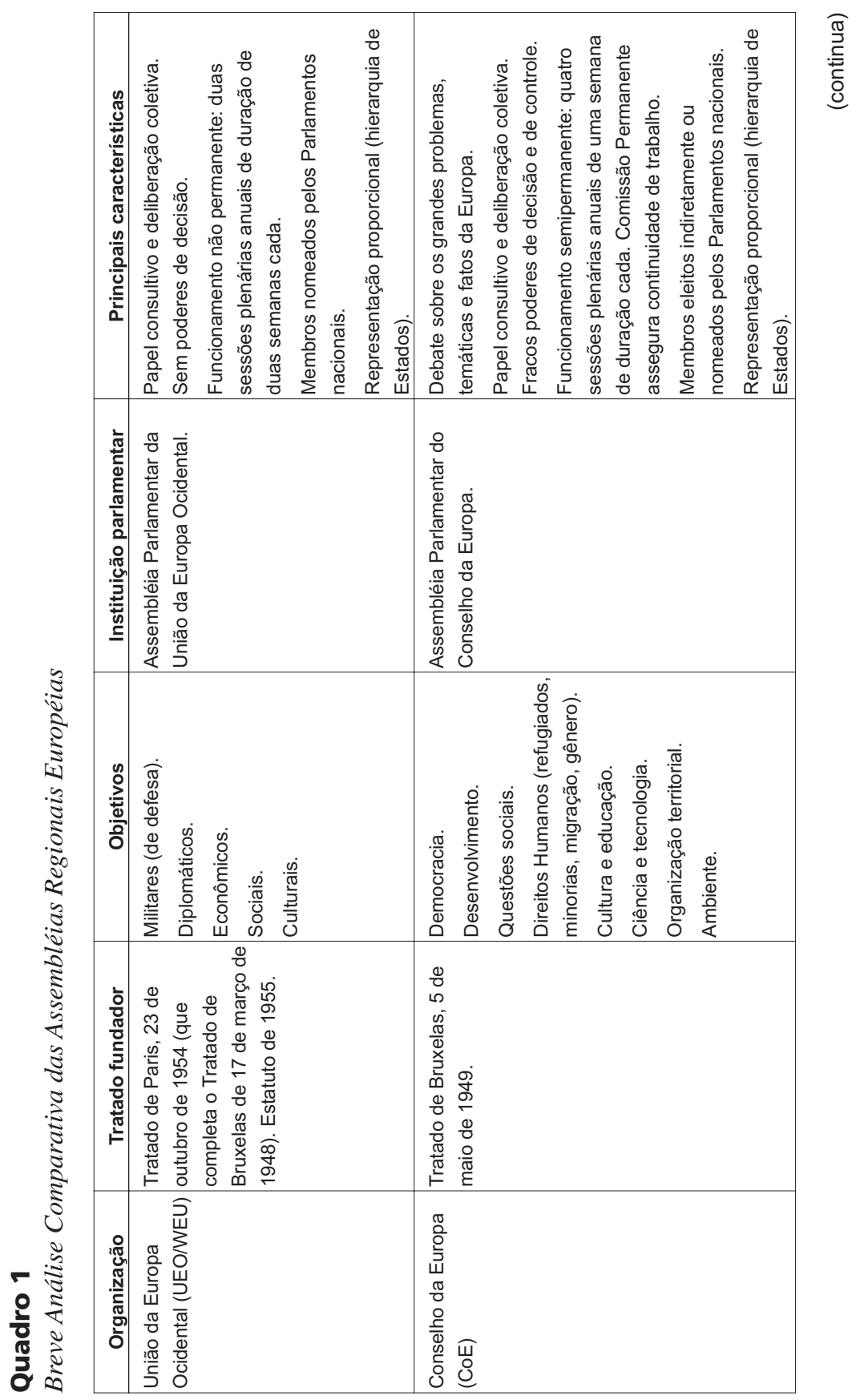




\section{Andrés Malamud e Luís de Sousa}

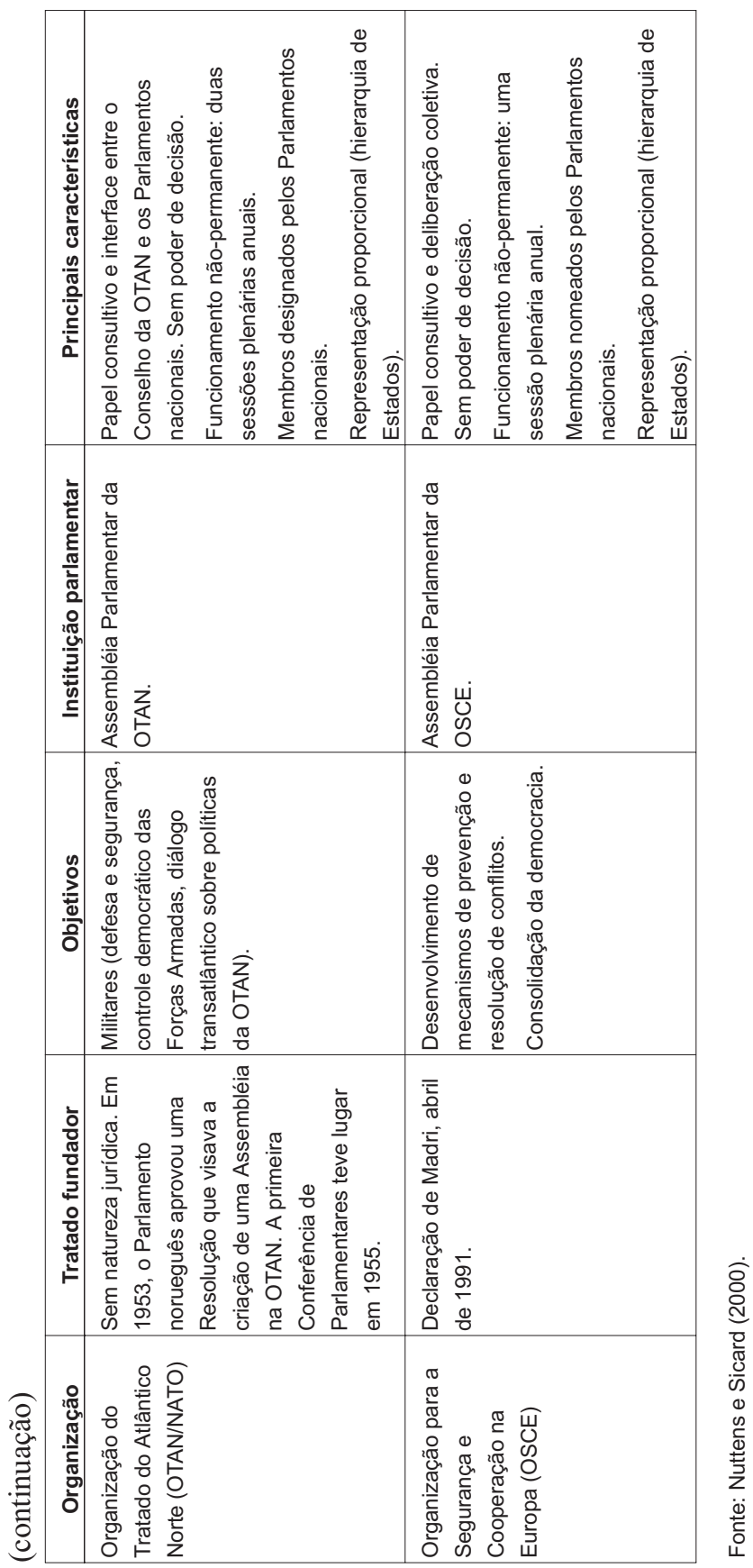


Parlamentos Supranacionais na Europa e na América Latina: Entre o Fortalecimento...

reúne os parlamentares dos países escandinavos; o Conselho de Consulta Interparlamentar dos países que constituem o Benelux (Bélgica, Países Baixos e Luxemburgo); a assembléia dos países do Báltico; a Assembléia Parlamentar de Cooperação Econômica dos países do Mar Negro; ou mesmo a Conferência Parlamentar dos países da Europa Central. Nenhuma destas iniciativas parlamentares regionais/internacionais participa do processo de integração europeu de forma tão relevante quanto o Parlamento Europeu. Contudo, tais iniciativas não podem deixar de ser mencionadas, porque a sobreposição de afiliação institucional dos vários países europeus e das próprias competências destas instituições se destaca como um elemento fundamental do modelo de integração política regional conseguido pelos Estados-nação na Europa do pós-1945. A evolução do processo de integração europeu seduz qualquer acadêmico que se debruce sobre as razões que conduzem ao sucesso e fracasso de opções e modelos institucionais. A integração européia construiu-se a partir de vários projetos institucionais, que, embora apontassem para o mesmo objetivo último, isto é, a criação de uma unidade política regional, apresentavam métodos bastante diferentes e, conseqüentemente, resultados díspares. Não só estes projetos coexistiram, como também competiram entre si. Enquanto alguns obtiveram sucesso na implantação e consolidação das suas instituições, outros foram relegados a um papel secundário.

De todas as iniciativas parlamentares regionais acima mencionadas, o Parlamento Europeu foi a única que desenvolveu poderes reais de decisão, tornando-se, assim, um elemento central da estrutura complexa de governança da UE. Para que melhor possamos compreender a evolução do Parlamento Europeu, passando de uma entre várias iniciativas parlamentares regionais ao primeiro Parlamento supranacional, será conveniente rever brevemente a estrutura e processo da Comunidade Européia (CE). 


\section{Evolução e competências do Parlamento Europeu}

Os fundadores dos Tratados de Roma de 1957 pretendiam uma ruptura com o passado. O fracasso do Conselho da Europa como resposta institucional à idéia de uma Europa unida era apontado por alguns ex-dirigentes do Conselho, como Paul-Henri Spaak, como um exemplo daquilo que o novo projeto deveria evitar a todo o custo. O novo projeto institucional seria baseado em um equilíbrio sustentável, entre intergovernamentalismo e supranacionalismo, e em um modelo constitucional liberal tripartido: um Poder Executivo que tomasse e implementasse as decisões; uma assembléia onde os vários assuntos e problemas seriam debatidos e deliberados; e um corpo judicial independente, com capacidade de rever decisões e de resolver conflitos que suscitassem problemas de legalidade.

A originalidade deste novo regime internacional reside no fato de adaptar a clássica divisão tripartida dos Poderes - Executivo, Legislativo e Judicial - aos novos arranjos institucionais que resultaram do equilíbrio entre o caráter intergovernamental e supranacional dos processos de decisão. Contudo, as competências dos três corpos políticos - Comissão, Conselho de Ministros e Parlamento Europeu encontram-se entrelaçadas a ponto de tornar difícil estabelecer uma divisão clara dos Poderes Executivo e Legislativo.

A função executiva é partilhada pela Comissão Européia e o Conselho de Ministros. A Comissão é um corpo político supranacional nomeado de mútuo acordo entre os Estados-membros, mas os seus membros exercem as suas prerrogativas independentemente das vontades e interesses dos seus respectivos governos. A Comissão representa os interesses da comunidade, atua como "guardiã dos Tratados" - no sentido de garantir a observância dos tratados e do Direito Comunitário, mesmo que isto implique em infligir sanções a um Estado-membro ou levá-lo a responder diante do Tribunal Europeu - 
e continua sendo a interface central do sistema de decisão (Mény, 1998:24). O Conselho de Ministros é um modelo clássico de corpo político intergovernamental composto por representantes dos Estados-membros que defendem os interesses dos seus próprios governos.

Embora estas duas instituições sejam denominadas de órgãos executivos, também desempenham funções legislativas. A Comissão detém um quase-monopólio do direito de iniciativa legislativa, além de ser responsável pela gestão e execução das políticas comuns, fiscalização da aplicação do Direito Comunitário (conjuntamente com o Tribunal de Justiça) e representação da UE em âmbito internacional. Também pode tomar decisões, autonomamente ou mediante delegação do Conselho, emitir pareceres e elaborar recomendações. O Conselho, por sua vez, possui amplos poderes de decisão: pode adotar regulamentos e diretivas, concluir acordos e tratados (que, no entanto, terão que ser negociados com a Comissão), retificar lacunas ou clarificar disposições nos tratados e partilhar competências orçamentais com o Parlamento.

O Parlamento Europeu, à semelhança dos Parlamentos nacionais, é eleito por sufrágio universal desde 1979, mas, ao contrário da maioria de regimes parlamentares europeus, o "governo europeu" não emana da maioria ou coligação representada no Parlamento. Em outras palavras, as eleições para o Parlamento Europeu não visam punir ou gratificar o "Poder Executivo europeu", ainda que o Parlamento Europeu tenha o direito de dissolver a Comissão por meio de um voto de censura com maioria de dois terços. O Parlamento Europeu tem também o poder de influenciar a adoção de legislação comunitária por intermédio do procedimento de cooperação e de fiscalização. Pode também iniciar ou instalar comissões de inquérito, questionar os Comissários sobre matérias relativas às várias políticas comuns, adotar resoluções e solicitar audiências com a Comissão, mas continua sem possuir competências legislativas gerais próprias. Exceto a 
adoção do orçamento, competência que partilha com o Conselho e que incide apenas sobre 3\% da despesa comunitária global, o Parlamento não dispõe de capacidade legislativa própria, nem proporciona aos eleitores a faculdade de escolherem diretamente o Executivo nas urnas. Este déficit institucional e democrático explica, de certo modo, a baixa participação nas eleições européias e a tendência de os partidos nacionais utilizarem este escrutínio para testar a governabilidade do partido ou coligação no poder.

Em adição a este "triângulo institucional" complexo, como é denominado no jargão comunitário, não deverá permanecer esquecido o "poder" vinculativo das decisões do Tribunal de Justiça das Comunidades Européias. Este "gigante adormecido" constitui um dos maiores motores do processo de integração europeu:

"O Tribunal de Justiça das Comunidades Européias é o órgão comunitário mais discreto e menos conhecido pelo público, mas também o maior responsável pela inesperada transformação da Comunidade (inicialmente com objetivos bastante limitados) em uma espécie de quase-federação. Se o 'governo dos juízes' existe em algum lugar, é em Luxemburgo! Mesmo quando o desenvolvimento político da Comunidade abrandou, ou mesmo paralisou, durante os finais da década de 1960 até o início da década de 1980, o Tribunal nunca desistiu de aplicar assertivamente a sua jurisprudência 'federativa', a qual viria a compensar a inércia dos governos nacionais e a incapacidade da Comissão de impulsionar eficazmente o processo de integração" (idem:25) $)^{3}$.

Este sumário pretende dar uma idéia geral da complexidade do aparelho de decisão da UE e uma breve indicação das várias tensões e batalhas de poder travadas entre as três principais instituições políticas da comunidade quando da revisão dos tratados. Não será inoportuno recordar que este aparelho de decisão se baseia em um equilíbrio, em constante evolução e ajuste, entre três fontes de legitimação e de interesses: os interesses e demandas do(s) povo(s) europeu(s), representado(s) pelos deputados e partidos que integram o Parlamento Europeu; os interesses e exigências dos Estados-membros representados 
no Conselho; e a missão e interesses comunitários - com expressão nos tratados, no Direito Comunitário e na jurisprudência do Tribunal Europeu - representados na Comissão.

\section{O Fortalecimento do Parlamento Europeu}

Na sua gênese, o Parlamento Europeu não se diferenciava substancialmente da assembléia do Conselho da Europa no que se refere ao seu desenho institucional e à amplitude das suas competências. O Parlamento Europeu, denominado "a Assembléia" até $19622^{4}$, era essencialmente um fórum composto por delegações nomeadas pelos Parlamentos nacionais. Detinha uma função consultiva limitada a um número reduzido de temáticas e de propostas legislativas antes de virem a ser submetidas à aprovação do Conselho.

No início dos anos 1970, a então Comunidade Econômica Européia atravessava um período turbulento causado quer por condicionalismos externos, como as sucessivas crises do petróleo, quer por disputas internas, como a posição intransigente do general de Gaulle adiante da futura adesão do Reino Unido, e pelo enfraquecimento do equilíbrio interno de poder entre as três principais instituições políticas da Comunidade. O poder pendia a favor do Conselho, que então detinha quase um monopólio sobre a adoção de legislação comunitária. Por outro lado, os interesses e preocupações dos cidadãos continuavam deficitariamente representados e permaneciam à margem das discussões e opções políticas tomadas pelos seus ministros no Conselho.

Em resposta a este déficit democrático e institucional que caracterizava o sistema político europeu, o Conselho decidiu adotar a introdução de eleições diretas dos membros do Parlamento Europeu. As primeiras eleições transnacionais européias ocorreram nos dias 7 e 10 de junho de 1979. Esta decisão revolucionária se tornaria crucial para 
a consolidação do equilíbrio interno, na medida em que daria ao Parlamento Europeu a capacidade institucional necessária para lutar, em pé de igualdade, por competências legislativas mais amplas e assumir um papel de relevo no triângulo institucional. Ao mesmo tempo, iniciava-se uma nova experiência de representação supranacional (Corbett, 1998).

Desde 1979, portanto, o Parlamento Europeu é eleito diretamente pelo voto dos cidadãos europeus para um período de cinco anos e é constituído de acordo com uma distribuição das cadeiras parlamentares que reflete, grosso modo, a dimensão geográfica dos vários Estados-membros, embora se possa argumentar que favorece os mais pequenos. O sistema de representação proporcional, que já era aplicado na maioria dos círculos nacionais desde 1979, foi finalmente adotado pela totalidade de Estados-membros durante as eleições européias de 1999. Os Quadros 2 e 3 mostram a evolução da distribuição de mandatos parlamentares em relação aos Estados-membros e formações partidárias.

O Tratado de Roma de 1957 também atribuiu ao Parlamento Europeu o poder de dissolver a Comissão por meio de um voto de censura com maioria de dois terços. Embora este instrumento ainda não tenha sido aplicado, a magnitude do seu efeito de dissuasão é considerável: em 1999, a simples ameaça de ser colocado em prática levou à demissão da Comissão Santer. Contudo, os fundadores dos tratados não atribuíram competências próprias nem poder de veto para que o Parlamento pudesse vir a assumir, a posteriori, um lugar central e um papel preponderante no processo de integração europeu. Como observou Olivier Costa (2001:19),

"Importa salientar que a existência do Parlamento Europeu não se deve tanto à vontade expressa dos fundadores de criar uma estrutura democrática supranacional, mas sim à busca de maior eficácia e legitimidade e a um fenômeno de mimetismo institucional". 
Parlamentos Supranacionais na Europa e na

América Latina: Entre o Fortalecimento...

\section{Quadro 2}

Parlamento Europeu: Cadeiras por Estado-membro e País Candidato*

\begin{tabular}{|c|c|c|c|}
\hline & $1999-2004$ & 2004-2007 & 2007-2009** \\
\hline Bélgica & 25 & 24 & 24 \\
\hline Bulgária & - & & 18 \\
\hline Chipre & - & 6 & 6 \\
\hline República Checa & - & 24 & 24 \\
\hline Dinamarca & 16 & 14 & 14 \\
\hline Alemanha & 99 & 99 & 99 \\
\hline Grécia & 25 & 24 & 24 \\
\hline Espanha & 64 & 54 & 54 \\
\hline Estônia & - & 6 & 6 \\
\hline França & 87 & 78 & 78 \\
\hline Hungria & - & 24 & 24 \\
\hline Irlanda & 15 & 13 & 13 \\
\hline Itália & 87 & 78 & 78 \\
\hline Letônia & - & 9 & 9 \\
\hline Lituânia & - & 13 & 13 \\
\hline Luxemburgo & 6 & 6 & 6 \\
\hline Malta & - & 5 & 5 \\
\hline Países Baixos & 31 & 27 & 27 \\
\hline Áustria & 21 & 18 & 18 \\
\hline Polônia & - & 54 & 54 \\
\hline Portugal & 25 & 24 & 24 \\
\hline Romênia & - & & 36 \\
\hline Eslováquia & - & 14 & 14 \\
\hline Eslovênia & - & 7 & 7 \\
\hline Finlândia & 16 & 14 & 14 \\
\hline Suécia & 22 & 19 & 19 \\
\hline Reino Unido & 87 & 78 & 78 \\
\hline Total & 626 & 732 & 786 \\
\hline
\end{tabular}

Fonte: <http://www.europa.eu.int/institutions/parliament/indexãen.htm> (Acessado em 26 de agosto de 2004).

* Os países estão aqui listados em ordem alfabética de acordo com os nomes de cada país em sua própria língua.

** Para 2007, prevê-se a adesão de dois países candidatos, Romênia e Bulgária, modificando o número total de deputados. 


\section{Andrés Malamud e Luís de Sousa}

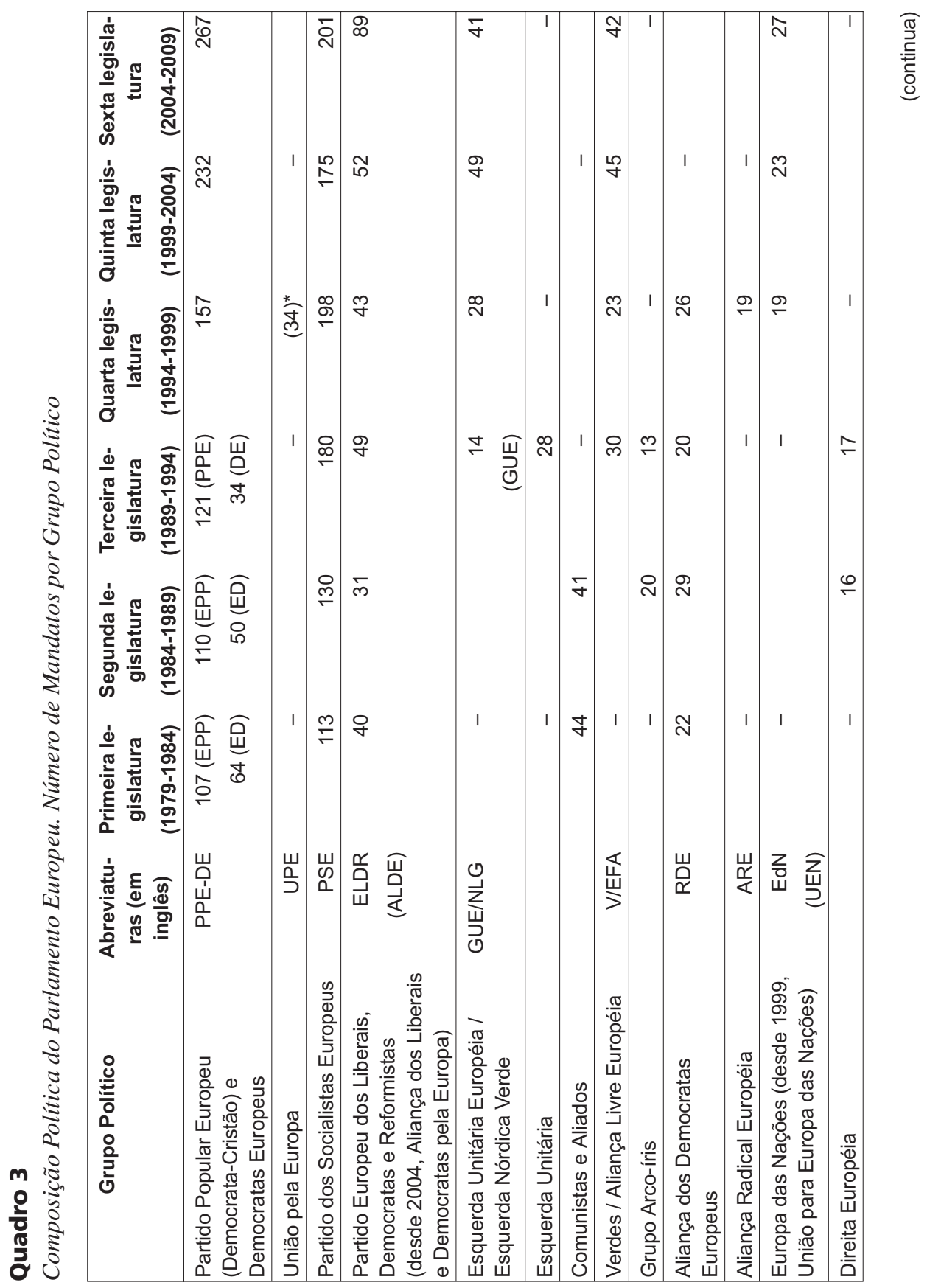


Parlamentos Supranacionais na Europa e na

América Latina: Entre o Fortalecimento...

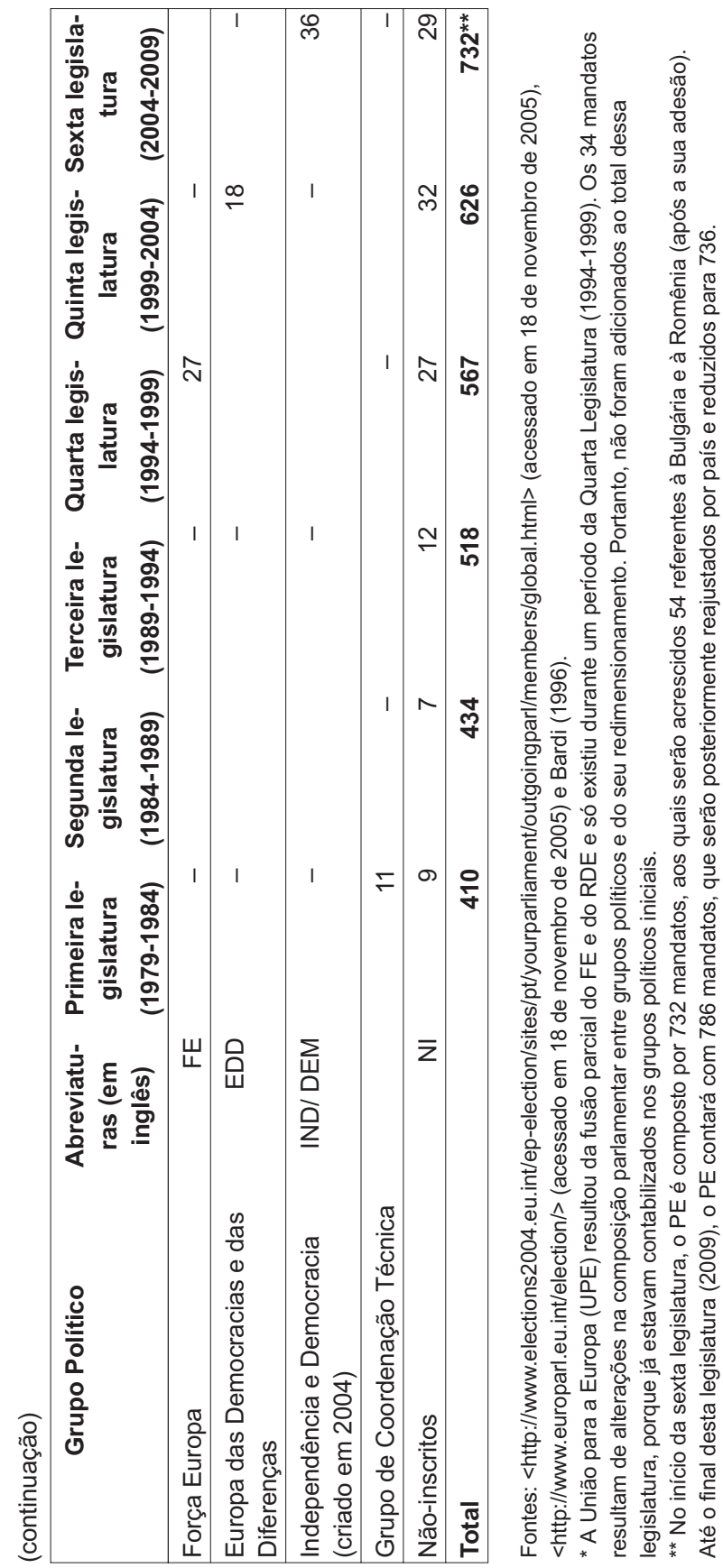


A criação e estruturação do Parlamento Europeu enquadra-se no padrão de desenho institucional comum às demais organizações ocidentais de caráter regional e/ou internacional que tiveram origem no pós-1945. A maioria destas organizações dispunha de um aparelho de decisão semelhante: um conselho responsável pela tomada de decisões e uma assembléia consultiva de natureza representativa mais ou menos permanente, como, por exemplo, a Organização das Nações Unidas (ONU), a União da Europa Ocidental, o Conselho da Europa e a Organização do Tratado do Atlântico Norte (OTAN/NATO). A dimensão simbólica associada a estas assembléias foi fundamental na conjuntura da reconstrução pós-guerra: não só serviram como interface entre o interesse coletivo das organizações regionais e os interesses particulares dos membros nacionais, como também facilitaram a socialização das elites políticas de países que se tinham defrontado no palco de guerra, reforçando, conseqüentemente, os níveis de confiança mútua e de cooperação internacional.

Havia, contudo, algo de maior envergadura e de inovador no projeto europeu visualizado por seus fundadores, Robert Schuman e Jean Monnet: a partilha de soberania. A idéia de construir um projeto político comum além do Estado-nação questionava o conceito tradicional de soberania territorial e levantava problemas de legitimidade, de poder e de accountability. O caráter supranacional deste novo projeto político seria desde o início confrontado com a adoção de uma assembléia plenária onde pudessem ser representadas e expressas posições e idéias diferentes entre as partes contratantes e onde as decisões aplicáveis à totalidade dos seus membros, que seriam tomadas em um nível muito mais restrito, pudessem ser objeto de escrutínio coletivo e sujeitas à deliberação da maioria. Era ainda prematuro falar de um "Parlamento do(s) povo(s) europeu(s)" como parte integrante de uma versão de democracia decalcada das experiências nacionais e transposta para o nível regional, uma idéia demasiado inovadora que não suscitaria o apoio ou aval de alguns países europeus, tais como o 
Parlamentos Supranacionais na Europa e na América Latina: Entre o Fortalecimento...

Reino Unido. Em vez disso, fundadores procuraram apenas uma resposta pragmática para um problema específico: a criação de uma instituição parlamentar que controlasse e assegurasse a legitimidade das atividades e decisões de caráter supranacional atribuídas à Alta Autoridade da Comunidade Européia do Carvão e do Aço (CECA).

É, por isso, legítimo questionarmo-nos sobre os fatores que contribuíram para a metamorfose do Parlamento Europeu, que de uma assembléia parlamentar internacional comum passou a ser um Parlamento supranacional único, com poderes de decisão concretos e um papel central no processo de integração europeu. Não existe uma explicação simples e direta. Talvez o fortalecimento do Parlamento Europeu se destaque como um processo de institucionalização singular, porque os membros das demais organizações internacionais nunca ambicionaram desenvolver uma estrutura política supranacional. De qualquer forma, é lícito comparar a sua transformação e o seu papel no processo de integração europeu com outras assembléias parlamentares regionais, cujos atores exprimiram uma intenção semelhante, isto é, a de criar um tipo de Parlamento supranacional. Sem pretender formular um modelo explicativo deste processo institucional, talvez possamos enumerar, com a ponderação devida, alguns desses fatores:

- Enquanto a institucionalização da CE tem como gênese uma organização edificada em torno de um problema transnacional específico para o qual foi ambicionado um modelo de gestão supranacional - a Comunidade Européia do Carvão e do Aço -, as demais organizações internacionais européias - designadamente o Conselho da Europa - tiveram desde o início um enfoque difuso sobre uma série de objetivos de carácter econômico, social, militar e institucional, sem vocação ou força suficiente para desencadear a criação de um aparelho de decisão supranacional. A regulamentação supranacional da produção do carvão e do aço - matérias-primas fundamentais quer para a in- 
dustrialização, quer para a produção de materiais bélicos - representava apenas um pequeno passo para nações que se tinham defrontado recentemente no campo de batalha pelo acesso e controle dos mesmos, mas provaria ser um salto gigantesco para o processo de integração europeu;

- Os atores, individuais e coletivos, por detrás deste empreendimento foram também co-responsáveis pela singularidade do percurso institucional da CE. Monnet, Schuman e Spaak exerceram cargos de prestígio no Conselho da Europa, mas abandonaram posteriormente este projeto institucional como reação ao "euroceticismo" e relutância do Reino Unido em avançar para novas formas de governo supranacionais. As posições inovadoras dos três seriam apoiadas por um número restrito de Estados - os Seis (Bélgica, França, Alemanha, Itália, Luxemburgo e Países Baixos) - empenhados na expansão do "método comunitário" a novas áreas de política econômica e social. Cada um destes países tinha razões fortes para acreditar no processo de integração econômica europeu: os países que constituem o Benelux tinham já implementado, com sucesso, uma união alfandegária; a gestão e funcionamento eficaz da Alta Autoridade da CECA conseguira promover um clima de confiança mútua e cooperação franco-alemã; e a Itália era berço de importantes líderes e movimentos federalistas;

- A eleição direta do Parlamento Europeu em 1979, e a subseqüente emergência de formações partidárias européias (os “europartidos"), seria o ponto de viragem no papel que esta instituição viria a desempenhar, quer no complexo triângulo institucional da $\mathrm{CE}$, quer no processo de integração europeu. $\mathrm{O}$ fortalecimento do Parlamento Europeu transformou-o na única assembléia parlamentar supranacional do mundo a gozar, simultaneamente, de legitimidade democrática, capacidade de decisão legislativa e poder de censura do governo. Trata-se, por isso, de um fórum político singular, em que os parlamentares 
europeus têm a possibilidade única de treinar as suas competências políticas em um ambiente genuinamente influente e supranacional. Contudo, pesa o fato de os parlamentares europeus serem freqüentemente recrutados entre políticos em fim de carreira ou dissidentes partidários. O mandato europeu continua a ser interpretado, pelas formações políticas nacionais, como um pára-quedas dourado para a reforma ou um esquema de compensação para oponentes internos incômodos às direções partidárias nacionais (Bardi, 1996; Scarrow, 1997).

A evolução do Parlamento Europeu nos últimos cinqüenta anos foi sintetizada de um modo elegante por Hix et alii (2003:191-192):

"Desde o seu modesto começo, o Parlamento Europeu [...] permaneceu marginal ao desenvolvimento da integração européia e às políticas da União Européia. Inicialmente, esta instituição era apenas uma assembléia consultiva composta por delegados enviados pelos Parlamentos nacionais. Cinqüenta anos depois, o Parlamento agora eleito por sufrágio direto possui competências legislativas e de investidura (ou remoção) do Executivo importantes, assim como todas as características e componentes de um Parlamento democrático resultantes do exercício desses poderes: organizações partidárias poderosas; comissões de trabalho bem organizadas; uma burocracia de apoio própria; e o constante lobbying de grupos de interesses privados".

Se, do ponto de vista interno, a institucionalização e fortalecimento do Parlamento Europeu é um processo contínuo e não necessariamente linear e progressivo, do ponto de vista externo, esta entidade política é o arquétipo ao qual será comparado e medido o desempenho de todo e qualquer projeto de Parlamento supranacional, em anos vindouros. O Parlamento Europeu tornou-se um modelo para aqueles que, em outras regiões, aspiram a institucionalizar os processos de integração em curso. Até a presente data, a América Latina é a região onde a sua influência se fez sentir com maior intensidade. 


\section{O Parlamento Latino-Americano (Parlatino)}

O Parlamento Latino-Americano (Parlatino) é a assembléia regional unicameral composta pelos membros de 22 Parlamentos nacionais da América Latina e Caraíbas ${ }^{5}$. Fundado em Lima, Peru, em dezembro de 1964 , foi posteriormente institucionalizado por um tratado internacional celebrado em Lima, em novembro de 1987. Desde 1992, a sua sede se encontra permanentemente localizada na cidade de São Paulo, Brasil. De acordo com os seus próprios Estatutos, os objetivos fundamentais desta entidade representativa regional são a defesa da democracia, a promoção da integração regional e o fortalecimento da cooperação entre parlamentares e Parlamentos em toda a América Latina. Possui personalidade jurídica e um orçamento que lhe é atribuído por todas as partes que participam do tratado. As línguas oficiais de trabalho são o espanhol e o português.

O Parlatino é integrado por delegações nacionais enviadas pelos Parlamentos-membros, à luz da experiência européia anterior a 1979. Cada delegação nacional pode nomear no máximo doze representantes, em uma proporção que reflete o peso dos grupos parlamentares nacionais. Se a delegação for inferior a doze membros, cada um dos representantes poderá acumular no máximo quatro votos (proxy voting), sem exceder o limite total de doze votos por delegação. Esta disposição atribui a todos os países o mesmo peso dentro do sistema de deliberação, independentemente da sua dimensão real. O quorum é obtido quando mais da metade das delegações nacionais estão representadas, desde que os seus membros respectivos representem pelo menos um terço do total de votos. O Parlatino reúne-se em sessão plenária uma vez por ano, na sua sede em São Paulo. Não tem poder de decisão, limitando-se apenas a aprovar acordos e a emitir recomendações e resoluções sem qualquer efeito vinculativo para terceiros. 
Estranhamente, no Parlatino não está representado nenhum dos territórios de expressão francesa da região: nem o Haiti, único Estado independente de expressão francesa, nem os departamentos ultramarinos franceses (Guiana Francesa, Guadalupe e Martinica). Contudo, e apesar do termo "latino" que figura na sua designação, o Parlatino inclui três membros de expressão holandesa: o Estado do Suriname e duas colônias ainda dependentes da Holanda - Aruba e Antilhas Holandesas.

No que diz respeito à sua representação territorial aberta, maleável e alargada, o Parlatino está mais próximo do modelo da assembléia parlamentar do Conselho da Europa que do Parlamento Europeu. A sua natureza intergovernamental e as escassas competências que lhe foram atribuídas, similares também à mencionada asssembléia européia, são comuns às demais assembléias regionais na América Latina - como será mostrado adiante. Contudo, importa notar que, ao contrário das três assembléias regionais que iremos analisar, o Parlatino não constitui o corpo representativo de uma organização regional qualquer. Desde a sua fundação, possui um estatuto próprio e independente.

O Parlatino ganhou algum reconhecimento internacional apesar das suas limitadas influência e competências. Em 1972, assinou um acordo com o Parlamento Europeu - que na época também era eleito indiretamente pelos Parlamentos nacionais - no sentido de estabelecer contatos permanentes e instituir uma Conferência Interparlamentar com periodicidade regular. A primeira ocorreu em Bogotá, em 1974, e a partir do ano seguinte seria repetida a cada dois anos com sede rotativa: no primeiro ano, teria lugar em um país latino-americano, no seguinte, em um Estado-membro da União Européia. Até a presente data, foram organizados dezesseis encontros, tornando-se assim o fórum bilateral com maior durabilidade. Os debates e resoluções produzidos são testemunho dos assuntos que dominaram a agenda transatlântica, das suas deficiências e da sua evo- 
lução. A relevância deste fórum diminuiu à medida que a democracia se consolidou e se estendeu à quase totalidade dos países da América Latina e os Parlamentos nacionais viram a sua existência e continuidade salvaguardadas. No momento em que a longa batalha da Conferência Interparlamentar em prol das instituições representativas e da defesa dos Direitos Humanos obteve sucesso, a incapacidade do fórum em encontrar uma missão de igual capacidade mobilizadora conduziu a uma redução gradual da sua importância. Embora os novos enfoques na qualidade das instituições e na reforma da administração pública estejam longe de suscitar o mesmo interesse das temáticas anteriores, a causa da integração regional encontrou novos defensores nos blocos sub-regionais que (re)emergiram no início dos anos 1990.

Apesar de existir um consenso generalizado em relação às matérias sobre a agenda comum, algumas questões, em particular as que dizem respeito ao comércio internacional ou à dívida externa, revelam uma assimetria persistente entre as duas regiões. A cooperação para o desenvolvimento constitui uma área sensível, na medida em que evidencia os desequilíbrios estruturais entre as duas regiões, mas nunca suscitou controvérsia entre as partes, porque a sua gestão depende, tão-somente, da vontade unilateral do "parceiro rico": a União Européia.

Em resumo, o Parlatino é mais uma instituição simbólica do que efetiva, capaz de acolher a deliberação de assuntos regionais e inter-regionais, mas sem qualquer perspectiva real de evolução para um órgão de decisão; de fato, carece de significado político e de enraizamento social. O seu mérito histórico foi o de constituir um reservatório de aspirações democráticas e procedimentos parlamentares durante a idade negra das ditaduras latino-americanas. As suas principais deficiências resultam, provavelmente, do fato de a sua existência, missão e funcionamento não estarem enquadradas em uma organização regional. 


\section{Parlamentos Supranacionais na Europa e na}

\section{O Parlamento Centro-Americano (Parlacen)}

O Parlamento Centro-Americano (Parlacen) constitui o órgão deliberativo do Sistema de Integração Centro-Americano (SICA). O SICA foi estabelecido em 1991 como uma organização complexa que reúne os países da América Central por um processo seletivo de geometria variável e se encontra edificado sobre o Mercado Comum Centro-Americano, fundado em 1960. Enquanto o SICA acolhe sete países da América Central - Belize, Costa Rica, El Salvador, Guatemala, Honduras, Nicarágua e Panamá -, o Parlacen exclui dois destes, Costa Rica e Belize, mas inclui um Estado das Caraíbas de expressão espanhola: a República Dominicana. À semelhança da UE, o SICA também possui uma entidade judicial de caráter supranacional, a Corte de Justiça Centro-Americana, e uma alta autoridade intergovernamental, a Cimeira Presidencial Centro-Americana. Introduz também a figura do secretário-geral, responsável pela coordenação de todo o sistema institucional. Embora o Parlacen tenda a ser visto como órgão parlamentar do SICA, na realidade não desenvolve nenhuma função legislativa.

A criação do Parlacen foi idealizada, pela primeira vez, na Declaração de Esquipulas I, assinada pelos vários presidentes dos países da América Central, com o intuito de pôr termo às rivalidades tradicionais e de promover a democracia e a paz na região. A cimeira presidencial, apoiada pelo Grupo Contadora, o Grupo de Apoio ${ }^{6}$ e a então Comunidade Européia, teve lugar em maio de 1986. Em uma Declaração posterior, que seria conhecida por Esquipulas II, produzida em 1987, os presidentes contratantes acordaram que a criação de um Parlamento centro-americano deveria ser um bastião da liberdade, independência e reconciliação em uma região devastada por anos a fio de chacina e instabilidade política. Entre o final de 1987 e início de 1989, Guatemala, El Salvador, Costa Rica, Nicarágua e Honduras 
assinaram e ratificaram, sucessivamente, o Tratado Constitutivo do Parlacen. Três protocolos adicionais foram assinados posteriormente, de modo a permitir algum tempo útil para o atraso gerado na eleição dos representantes nacionais e facilitar a adesão do Panamá ao tratado, embora a sua incorporação tivesse lugar apenas em 1999. O Parlamento foi, finalmente, estabelecido em outubro de 1991, quando ocorreu a sua primeira sessão plenária na Cidade de Guatemala, que passaria a ser a sua sede permanente. A Costa Rica viria a retirar a sua participação, enquanto a República Dominicana passaria a fazer parte do processo em 1999.

Desde 28 de outubro de 1991, o número de deputados do Parlacen passou de um total de 65, representando quatro países e treze partidos políticos, para os atuais 132 deputados, representando seis países e 42 partidos políticos. Os deputados são eleitos diretamente por um período de cinco anos pelos cidadãos eleitores de cada Estado-membro, podendo cada país preencher uma quota máxima de vinte representantes. Cada Estado-membro tem o direito de enviar dois deputados adicionais: o presidente e vice-presidente em fim de mandato. $\mathrm{O}$ Parlamento está também aberto à participação de representantes, com o status de observadores, dos demais Parlamentos regionais, tais como o Parlatino, o Parlamento Andino e o Parlamento Europeu, ou de Estados não signatários da região, como Porto Rico e México. Os primeiros assistiram aos trabalhos do Parlacen desde a sua criação, ao passo que os últimos se associaram pouco tempo mais tarde. Os representantes nacionais dividem-se em três grupos parlamentares: o maior grupo representa o centro do espectro político, os outros dois cobrem as alas ideológicas, esquerda e direita respectivamente.

Tal como prevê o primeiro artigo do tratado fundador, as competências legislativas do Parlacen resumem-se à capacidade de proposta, análise e recomendação. Contudo, o tratado também confere ao Parlamento o poder de eleger, nomear e dissolver o mais alto executivo 
Parlamentos Supranacionais na Europa e na América Latina: Entre o Fortalecimento...

de todas as instituições pertencentes ao SICA. Por mais estranho que pareça, todavia, este órgão parlamentar não foi provido de capacidade legislativa, mas foi capacitado para nomear e fiscalizar uma série de técnicos e funcionários. Também compete a ele requerer informação sobre qualquer atividade da organização e emitir recomendações sobre os relatórios de atividade dos demais órgãos do SICA que lhe são submetidos para apreciação, sem, contudo, interferir no seu funcionamento. No que diz respeito aos procedimentos de votação, o Parlacen decide por maioria absoluta, exceto no que se refere à revisão dos seus estatutos internos: neste caso, é necessária uma maioria qualificada. Quanto ao orçamento do Parlamento, todos os Estados-membros contribuem equitativamente.

Depois de mais de uma década de existência, o histórico do Parlacen é misto: embora demonstre resultados positivos no que diz respeito à ampliação da sua composição, não apresenta qualquer progresso significativo no que se refere ao aprofundamento das suas competências. Se, por um lado, contribuiu para a pacificação e crescente interdependência entre as sociedades que representa, por outro lado, não evoluiu suficientemente para se tornar um ator crucial no, já por si frágil, processo de integração da região centro-americana.

\section{- Parlamento Andíno (Parlandino)}

O Parlamento Andino (Parlandino) é o órgão deliberativo do Sistema Andino de Integração (AIS). O Pacto Andino ${ }^{7}$, antecessor do AIS, foi fundado em 1969 com o objetivo de colmatar as lacunas e deficiências da Associação Latino-Americana de Livre Comércio (ALALC), um projeto regional mais vasto cujo insucesso se deve, sobretudo, à reprodução interna da divisão entre países mais e menos desenvolvidos - precisamente, o que em tempos, fora criticado em relação ao funcionamento do sistema político internacional. Os fundadores do Pacto Andino inspiraram-se no projeto europeu, que co- 
meçava a consolidar-se nesse período, e decidiram formalizar o processo de integração por meio da criação de um conjunto de instituições que combinassem, simultaneamente, um sistema de votação majoritário e autoridades com poder vinculativo supranacional. No final dos anos 1980, após vários anos de turbulência e de paralisia institucional causados por razões domésticas e pelo fracasso na criação da tão desejada interdependência econômica na região, os presidentes nacionais decidiram relançar o processo de integração com aspirações mais modestas e um desenho institucional sóbrio. Contudo, a estrutura institucional da região continua, de um modo geral, semelhante à da UE: o complexo institucional compreende uma Comissão, um Parlamento, um Tribunal de Justiça, um Conselho de Ministros e um Conselho Presidencial, além de um conjunto de instituições de caráter técnico, tais como agências financeiras, fóruns de consulta junto da sociedade civil e, até mesmo, uma universidade. Com o mérito que lhe é devido, na prática, as competências reais e desempenho destas instituições regionais ficam aquém das do modelo europeu.

Das várias instituições mencionadas, o Parlandino é o órgão de representação dos povos da Comunidade Andina e possui caráter supranacional. O seu tratado fundador foi assinado em 1979 e entrou em vigor em 1984. A sua sede foi estabelecida em Bogotá, Colômbia, e em 1997 foi introduzida a eleição direta dos seus representantes. O processo eleitoral devia ter início durante os cinco anos seguintes; todavia, até a presente data, só Venezuela e Equador colocaram o pressuposto em prática. Nos restantes países, a eleição direta ou está agendada para os próximos anos, como é o caso da Colômbia e do Peru, ou está sujeita a uma revisão constitucional prévia, no caso da Bolívia.

O Parlandino é composto por 25 deputados, cinco por cada Estado-membro. Há cinco comissões permanentes, integradas por cinco elementos, um de cada nacionalidade. O Parlandino pode aprovar quatro tipos de atos - decisões, acordos, declarações e recomenda- 
ções - mediante maioria absoluta, mas carece de qualquer poder de decisão. As suas competências estão limitadas ao enquadramento e fomento do processo de integração, por meio da promoção de legislação entre os Estados-membros, da cooperação e coordenação de iniciativas com os Parlamentos nacionais, países terceiros ou outras organizações de integração regional que formulem recomendações relativamente ao orçamento da Comunidade Andina.

Em 2004, o Parlandino celebrou o seu $25^{\circ}$ aniversário, metade da idade do modelo em que sempre se inspirou, o Parlamento Europeu. As diferenças entre as duas assembléias regionais são evidentes: a começar pela prolongada e atrasada eleição direta dos seus representantes, seguida pela composição que não respeita as proporções demográficas dos Estados-membros, e terminando na ausência de poderes de decisão. Embora o Parlandino já tenha trilhado bastante caminho, tendo em conta a sua jovem existência, não deixa de ser uma realidade que evoluiu pouco ao longo dos anos, tal como o bloco regional em que se insere (Bonilla, 2001; Malamud, 2004). Os interesses nacionais contraditórios, a instabilidade institucional, a turbulência econômica e os conflitos políticos entre os Estados-membros transformaram a Comunidade Andina em um exemplo a não ser seguido. Precisamente, os primeiros passos do Mercosul seriam baseados na tentativa de evitar a repetição dos fracassos andinos (Caputo, 1999; Pereira, 2000).

\section{A Comissão Parlamentar Conjunta do Mercosul (CPCM)}

O Mercosul, designação abreviada de Mercado Comum do Sul, é o mais recente bloco regional da América Latina e integra dois velhos rivais, Argentina e Brasil, e dois “Estados-tampão", Paraguai e Uruguai. Fundado em 1991 pelo Tratado de Assunção e consolidado em 1994 no Protocolo de Ouro Preto, o Mercosul visava criar, primaria- 
mente, um mercado comum no Cone Sul por meio da eliminação de obstáculos intra-regionais à circulação de bens, capital e serviços embora algumas medidas também tenham sido tomadas em relação à livre circulação de pessoas. Os fundadores deste novo projeto de integração regional tinham presente duas realidades históricas: a experiência de sucesso da União Européia e a experiência negativa da integração na América Latina. Os riscos de insucesso seriam reduzidos, por um lado, evitando uma institucionalização prematura e, por outro, depositando o controle do processo nas mãos dos presidentes nacionais (Malamud, 2003). Desde então, o Mercosul desenvolveu-se como uma organização estritamente intergovernamental: não obstante a sua personalidade jurídica lhe permita tomar parte em negociações internacionais representando os seus membros, é sempre necessária a unanimidade para adotar uma decisão coletiva. A soberania nacional não foi nem delegada nem partilhada e todos os órgãos de decisão do Mercosul são compostos exclusivamente por altos representantes governamentais dos Estados contratantes (Peña, 1998). Existem, porém, algumas instituições que, embora desprovidas de poderes de decisão, convém serem analisadas, tais como a Comissão Parlamentar Conjunta do Mercosul (CPCM).

A CPCM é o órgão do Mercosul que reúne as delegações dos quatro Congressos Nacionais. Entre os cinco Parlamentos regionais analisados neste artigo, a CPCM é a única que ainda não adquiriu o status de Parlamento, pelo menos na sua designação oficial. O Tratado de Assunção, celebrado em março de 1991, de fato indicava este órgão como o mecanismo que proporcionaria a criação de um mercado comum. Contudo, ainda não era claro o modo como a CPCM contribuiria para a realização do objetivo último de integração, pois o tratado não lhe endossara qualquer tipo de atribuições específicas; em alternativa, o mesmo tratado mencionara a obrigação dos Executivos nacionais manterem os respectivos Congressos Nacionais informados dos progressos conseguidos no projeto de integração em curso. 
Somente por meio do Protocolo de Ouro Preto, celebrado em dezembro de 1994, é que foram definidos a estrutura institucional do Mercosul e o formato atual da CPCM. Esta passou a constituir um órgão representativo dos Parlamentos nacionais, responsável pela transposição acelerada dos procedimentos do Mercosul para a ordem jurídica dos Estados-membros. Adicionalmente, foi incumbida de desempenhar um papel subsidiário nas iniciativas de harmonização de políticas e um papel consultivo em relação ao Conselho do Mercado Comum, o órgão regional supremo composto pelos ministros das Relações Exteriores e da Economia dos países signatários. Compete à CPCM exercer as suas funções e competências mediante a elaboração de recomendações, disposições e declarações (Caetano e Perina, 2000; 2003). Contudo, nenhum destes atos possui qualquer efeito vinculativo. Neste contexto de reduzidos poderes de decisão, recebeu ainda a missão, pouco clara, de estudar e criar as condições necessárias para a eventual criação de um Parlamento regional para o projeto Mercosul.

O Protocolo de Ouro Preto estabeleceu que a CPCM seria constituída por um total de 64 membros. A cada país competia eleger, no máximo, dezesseis representantes entre prestigiados advogados, incluindo membros das duas Câmaras nacionais - notando-se que os quatro Estados-membros do Mercosul possuem um sistema parlamentar bicameral. Os representantes nacionais da CPCM são agrupados em seções nacionais compostas por deputados e senadores. O Protocolo recomendou a eleição por um termo de dois anos, de modo a possibilitar alguma continuidade de trabalho, mas deixou ao critério dos Parlamentos dos Estados-membros a decisão final sobre a duração do mandato e a definição da data e mecanismo de eleição.

O Protocolo também estabeleceu que a CPCM se reunisse, no mínimo, duas vezes por ano, com a ressalva de que a validade do encontro dependeria da participação dos representantes de todos os Estados-membros. Mais ainda, todas as decisões da CPCM teriam que 
ser tomadas por consenso entre as partes, a regra de ouro aplicável a todos os órgãos constitutivos do Mercosul. O caráter extremamente intergovernamental destas disposições neutraliza uma das principais funções exercidas no seio de qualquer instituição parlamentar: a votação. Nem mesmo a presidência da CPCM é eleita pelo plenário, não obstante um sistema de rotação, por um período de seis meses, tenha sido adotado, à semelhança do estabelecido para a presidência do Mercosul como um todo. Os vários órgãos de decisão que compõem o Mercosul são coadjuvados por um Secretariado Administrativo Permanente. O secretário, que não pode exercer funções de deputado a nível nacional, é também nomeado, rotativamente, pelos quatro Estados-membros, mas, ao contrário das presidências, a sua comissão de serviço dura dois anos em vez de seis meses.

O Estatuto Interno da CPCM contempla a possibilidade de criar comissões de trabalho, desde que não tenham um caráter estatutário permanente e funcionem apenas como instrumentos ad hoc. Esta provisão não permite a especialização dos parlamentares, nem lhes proporciona uma carreira estável ou uma formação progressiva das suas aptidões. Como regra, a CPCM reúne-se no Estado-membro que detém, temporariamente, a presidência. O seu orçamento é atribuído em iguais proporções pelos Estados-membros do Mercosul. Desde, pelo menos, meados da década de 1990, um número crescente de políticos, acadêmicos e líderes de opinião têm se mobilizado em favor da criação e fortalecimento de um Parlamento do Mercosul (Caetano e Antón, 2003; CEFIR, 1998; SM, 2004; Vazquez, 2001). Até a data, permanecem apenas boas intenções.

\section{Conclusões Comparativas}

De todas as instituições internacionais designadas como Parlamentos, apenas o Parlamento Europeu desenvolveu um caráter verdadeiramente supranacional e poderes efetivos próprios. Os restantes estão ainda aquém desta realidade (ver também Vieira Posada, 2000). 
A história, estrutura, competências e funções destas instituições são bastante variáveis, tal como o grau de legitimidade de que gozam. A análise dos Parlamentos regionais apresentada neste artigo teve como objetivo, por um lado, a homogeneização dos conceitos utilizados nesta área de estudos e, por outro, a apresentação de uma imagem comparativa de cinco instituições que reclamam a mesma designação.

Depois de examinados os cinco Parlamentos regionais das duas regiões consideradas, as diferenças encontradas entre o Parlamento Europeu e os quatro proto-Parlamentos da América Latina são significativas, qualquer que seja a dimensão considerada. O Quadro 4 oferece uma comparação das principais diferenças (e semelhanças) entre os cinco casos de estudo.

No que diz respeito à dimensão representativa, apenas o Parlacen designa os seus membros por eleições diretas, à semelhança do Parlamento Europeu. Todavia, não são levadas em conta as diferenças demográficas entre os vários círculos eleitorais, isto é, os Estados-membros. Em relação aos processos de decisão, a nenhum Parlamento regional da América Latina foram atribuídos quaisquer poderes legislativos. O Parlacen, novamente, destaca-se como o único que possui competências de fiscalização sobre os restantes órgãos da organização. Contudo, tem tido resultados menos brilhantes do que o Parlatino e o Parlandino no que se refere à institucionalização de comissões estatutárias permanentes e especializadas. Em contraste, o Parlamento Europeu figura, cada vez mais, com capacidades nas quatro dimensões consideradas. Vários fatores confluem para a explicação desta diferença. A seguir, mencionamos cinco que consideramos fundamentais e sugerimos algumas pistas para uma investigação mais aprofundada sobre o assunto.

O primeiro fator que distingue a evolução dos Parlamentos regionais nas duas regiões em análise é o tempo: existe uma diferença de duas a 


\section{Andrés Malamud e Luís de Sousa}

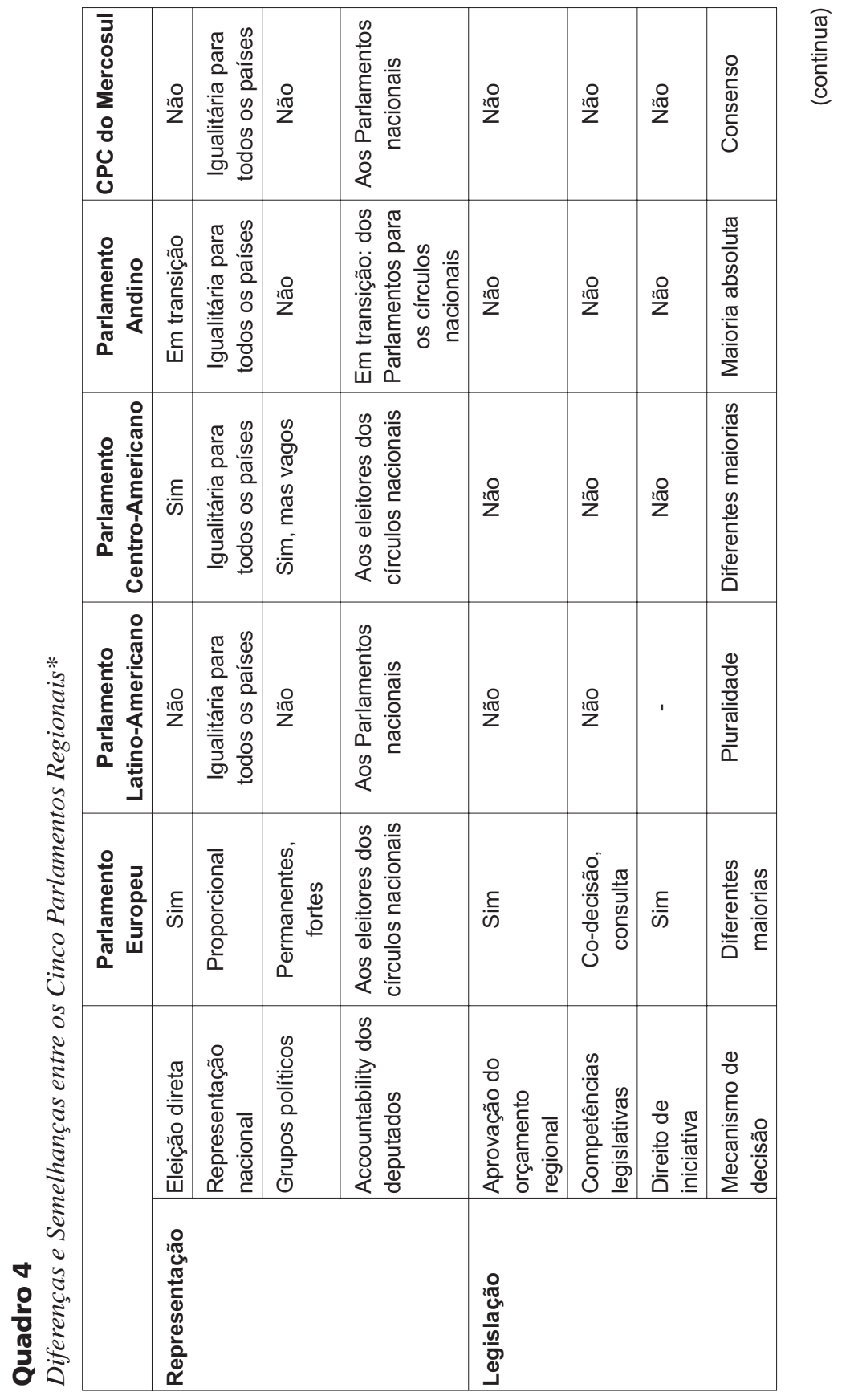


Parlamentos Supranacionais na Europa e na

América Latina: Entre o Fortalecimento...

\begin{tabular}{|c|c|c|c|c|c|c|c|}
\hline $\begin{array}{l}\overline{5} \\
0 \\
0 \\
0 \\
\sum_{0}^{0} \\
0 \\
0 \\
0 \\
0 \\
0\end{array}$ & $\underset{20}{2}$ & $\stackrel{200}{Z}$ & $\stackrel{i \pi}{Z}$ & $\frac{d}{\frac{\delta}{\delta}}$ & $\frac{\Omega}{2 \pi}$ &  & $\begin{array}{l}\mathbb{8} \\
\mathbb{0} \\
\mathbb{1}\end{array}$ \\
\hline 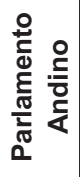 & $\stackrel{20}{2 \pi}$ & $\stackrel{200}{Z}$ & $\frac{0}{2 \pi}$ &  & $\frac{\Omega}{2 \pi}$ & $\frac{E}{\omega}$ & 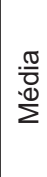 \\
\hline 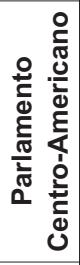 & $\begin{array}{l}\frac{\bar{\pi}}{0} \\
\overline{\frac{N}{0}} \\
0\end{array}$ & $\begin{array}{l}\frac{\bar{\pi}}{0} \\
\frac{0}{\pi} \\
\frac{0}{0}\end{array}$ & $\begin{array}{l}\frac{\bar{\pi}}{0} \\
\frac{\pi}{\pi} \\
\square\end{array}$ & $\frac{8}{\frac{8}{8}}$ & $\frac{o}{2 \pi}$ & $\frac{E}{\omega}$ & $\begin{array}{l}\frac{\pi}{\bar{O}} \\
\stackrel{0}{\mathbb{N}} \\
\sum\end{array}$ \\
\hline 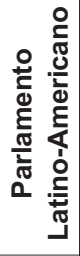 & $\frac{20}{Z}$ & i⿱ & $\frac{0}{2 \pi}$ & 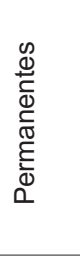 & $\frac{0}{2 \pi 0}$ & 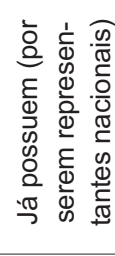 & $\begin{array}{l}\mathbb{U} \\
\mathbb{W} \\
\text { एँ }\end{array}$ \\
\hline 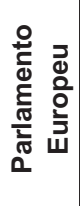 & $\frac{E}{\omega}$ & $\stackrel{E}{\omega}$ & $\stackrel{E}{\bar{\omega}}$ & 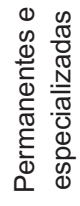 & $\frac{E}{\omega}$ & $\frac{E}{\omega}$ & $\begin{array}{l}0 \\
\text { 오 }\end{array}$ \\
\hline & 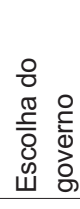 & 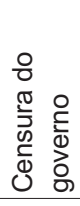 & 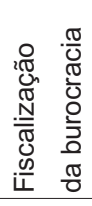 & 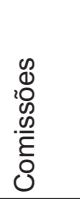 & 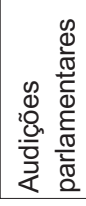 & 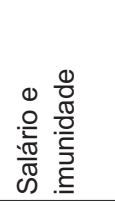 & 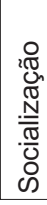 \\
\hline & 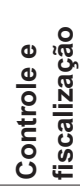 & & & 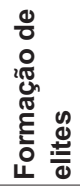 & & & \\
\hline
\end{tabular}


quatro décadas entre o início do processo de integração europeu e os processos em curso na América Latina; portanto, algumas das diferenças de desenvolvimento institucional assinaladas poderão resumir-se a uma questão de maturidade.

O segundo fator é a sequiência: a atual estrutura da UE foi construída a partir do tão falado "método Monnet", isto é, a função precede a forma e o "incrementalismo" é preferido à institucionalização prematura. Em contraste, algumas das experiências da América Latina tentaram, sem sucesso, emular o resultado do processo de integração europeu, mas descuidando do seu método.

Em terceiro lugar, existe uma grande disparidade no nível de integração conseguido: enquanto a UE é já um mercado comum e continua a consolidar a sua união econômica, nenhum dos projetos latino-americanos alcançaram sequer o nível de união aduaneira. Por conseguinte, a estrutura institucional necessária para um tipo de organização poderá ser inadequada aos requisitos das outras.

Em quarto lugar, o grau de sucesso na criação de instituições regionais não pode estar desassociado do modo efetivo como essas instituições funcionam em nível nacional. Em outras palavras, o caráter precário e de instabilidade das instituições nacionais não pode servir de base estável para a construção de instituições que visam a integração política regional.

Em último lugar, a maioria dos países europeus constituem regimes parlamentares ou semiparlamentares, enquanto todos os países da América Latina são democracias presidencialistas. Uma conseqüência desta variação institucional é que o papel dos Parlamentos nacionais em todo o processo de integração é inevitavelmente diferente em uma e outra região: se, na Europa, os Parlamentos nacionais são entendidos como instituições supremas, em que os governos são constituídos e dissolvidos, na América Latina, as eleições, autoridade e sobrevivência dos governos são independentes da vontade parlamen- 
tar. Portanto, é razoável esperar que os chefes de governo de regimes presidencialistas tencionem replicar, em nível regional, um esquema que lhes tem proporcionado dividendos em nível nacional (Malamud, 2005).

O princípio que baseia este último argumento é o de que, mesmo nos processos de integração regional, a natureza presidencialista ou parlamentar dos regimes dos Estados-membros importa e tem implicações diretas, especialmente no que diz respeito à criação e desempenho de Parlamentos regionais. Conseqüentemente, também os partidos políticos cumprem um papel diferente em um ou outro contexto institucional regional. Não seria inoportuno que os reformadores destes processos levassem em consideração estas conclusões, pois, como já foi referido por alguns autores, um sistema parlamentar poderá não ser a solução mais adequada para governar uma democracia multiestatal (Fabbrini, 2004; McKay, 2001). Nota-se ainda que as implicações desta hipótese dizem respeito não apenas ao futuro dos Parlamentos regionais na América Latina, mas a qualquer processo de integração política, incluindo o europeu. Fóruns birregionais, tais como a Conferência Interparlamentar Europa-América Latina ${ }^{8}$, poderiam desempenhar um papel mais significativo e de mútuo interesse, ajudando os Parlamentos nacionais a prevenir possíveis insucessos geralmente associados à criação de expectativas quiméricas.

Os Parlamentos regionais podem contribuir para a criação, a longo prazo, de alicerces complementares da integração, tais como: a construção de uma identidade regional entre as elites políticas; o fortalecimento da presença simbólica da organização regional no seio da opinião pública e a sua promoção em países terceiros; e a intensificação da comunicação intra-regional. Contudo, estas funções não são nem exclusivas, nem características fundamentais de uma instituição parlamentar. Se a reforma dos Parlamentos regionais é para ser tomada seriamente, a distinção entre funções constitutivas e complementares não pode ser negligenciada. Como ensina a história, embarcar 
em propostas pouco realistas, sejam elas baseadas na emulação acrítica, sejam resultantes de uma compreensão insuficiente do contexto, condenará qualquer empresa ao fracasso ou, na melhor das hipóteses, à irrelevância.

\section{Notas}

1. Por regional, entenda-se a dimensão internacional e/ou os processos de decisão de natureza intergovernamental ou supranacional em um espaço contíguo que afeta várias jurisdições territoriais nacionais. Não se refere ao nível intermédio de governo entre o local e o nacional dentro de uma jurisdição estatal.

2. A Declaração de Roma de 27 de outubro de 1984 sublinhou a importância de a União da Europa Ocidental vir a fazer parte do complexo da política de defesa européia. Esta intenção política seria, posteriormente, posta em prática pelo Tratado de Maastricht de 1991.

3. Esta e as demais citações de textos em língua estrangeira foram livremente traduzidas por nós.

4. O Ato Único Europeu de 1986 tornaria, finalmente, oficial a designação de Parlamento Europeu.

5. Os países signatários são: Argentina, Aruba, Bolívia, Brasil, Chile, Colômbia, Costa Rica, Cuba, República Dominicana, Equador, El Salvador, Guatemala, Honduras, México, Antilhas Holandesas, Nicarágua, Panamá, Paraguai, Peru, Suriname, Uruguai e Venezuela.

6. O Grupo Contadora foi fundado em 1983 com a participação do México, Colômbia, Venezuela e Panamá. O Grupo de Apoio foi estabelecido, posteriormente, em 1985 e era composto pela Argentina, Uruguai, Brasil e Peru. A missão de ambos os grupos era a de contribuir para uma solução negociada dos conflitos na América Central e os seus princípios diretores eram, fundamentalmente, quatro: autodeterminação, não-intervenção, desmilitarização e democratização. Em 1986, os dois grupos fundiram-se em um só, que viria a ser conhecido como Grupo do Rio.

7. O Pacto Andino foi assinado pela Bolívia, Chile, Colômbia, Equador e Peru. Em meados dos anos 1970, a Venezuela integrou-se ao processo, ao passo que o Chile o abandonou. 


\section{Parlamentos Supranacionais na Europa e na América Latina: Entre o Fortalecimento...}

8. Este fórum, cujo terceiro encontro teve lugar em Puebla entre 17 e 19 de março de 2004, inclui a participação de delegados dos cinco Parlamentos regionais analisados neste artigo.

\section{Referências Bibliográficas}

BARDI, Luciano. (1996), "Report: Transnational Trends in European Parties and the 1994 Elections of the European Parliament". Party Politics, vol. 2, n 1, pp. 99-114.

BONILLA, Adrián. (2001), Entre el Deseo y la Ficción. Interdependencia e Integración en la Región Andina. Trabalho apresentado no XXIII LASA World Congress, Washington D.C., 6-8 de setembro.

CAETANO, Gerardo e ANTÓN, Romeo Pérez. (2003), "Hacia un Parlamento del MERCOSUR”, in G. Caetano e R. Perina (eds.), La Encrucijada Política del Mercosur. Parlamentos y Nueva Institucionalidad. Montevideo, CLAEH-OEA.

CAETANO, Gerardo e PERINA, Rubén (eds.). (2000), Mercosur y Parlamentos. El Rol de los Congresos en la Democracia y la Integración. Montevideo, CLAEH-OEA.

(eds.). (2003), La Encrucijada Política del Mercosur. Parlamentos y Nueva Institucionalidad. Montevideo, CLAEH-OEA.

CAPUTO, Dante. (1999), Personal Interview (former Argentine Foreign Minister). Buenos Aires, setembro.

CEFIR - Centro de Formación para la Integración Regional. (1998), La Comisión Parlamentaria Conjunta. Una Visión de su Funcionamiento. Resumo apresentado no workshop Perspectivas Institucionales del Mercosur: Organización y Funcionamiento de la Comisión Parlamentaria Conjunta, organizado pelo CEFIR e pela Comissão Parlamentar Conjunta do Mercosul. Buenos Aires, 2-4 de junho.

CORBETT, Richard. (1998), The European Parliament's Role in Closer EU Integration. Basinstoke, Palgrave. 
COSTA, Olivier. (2001), Le Parlement Européen, Assemblée Délibérante. Bruxelas, Institut d'Études Européennes.

FABBRINI, Sergio. (2004), “Transatlantic Constitutionalism: Comparing the United States and the European Union”. European Journal of Political Research, vol. 43, n 4, pp. 547-569.

HIX, Simon, RAUNIO, Tapio e SCULLY, Roger. (2003), "Fifty Years On: Research on the European Parliament". Journal of Common Market Studies, vol. 41, no 2, pp. 191-202.

MALAMUD, Andrés. (2003), "Presidentialism and Mercosur: A Hidden Cause for a Successful Experience", in F. Laursen (ed.), Comparative Regional Integration: Theoretical Perspectives. London, Ashgate, pp. 53-73.

(2004), "Regional Integration in Latin America. Comparative Theories and Institutions”. Sociologia. Problemas e Práticas, n 44, Lisboa, pp. 135-154.

(2005), "Presidential Diplomacy and the Institutional Underpinnings of Mercosur. An Empirical Examination". Latin American Research Review, vol. $40, \mathrm{n}^{\circ} 1$, pp. $138-164$.

MCKAY, David. (2001), Designing Europe: Comparative Lessons from the $\mathrm{Fe}$ deral Experience. Oxford, Oxford University Press.

MÉNY, Yves. (1998), The French Political System. Paris, La Documentation Française.

NUTTENS, Jean-Dominique e SICARD, François. (2000), Assemblées Parlementaires et Organisations Européennes. Paris, La Documentation Française.

PEÑA, Félix. (1998), "El Desarrollo Institucional del Mercosur”, in Comunidad Andina y Mercosur. Desafíos Pendientes de la Integración en América Latina. Bogotá, Ministerio de Relaciones Exteriores de Colombia y Corporación Andina de Fomento.

PEREIRA, Celso. (2000), Personal Interview (Brazilian diplomat). Brasília, dezembro.

RITTBERGER, Berthold. (2003), "The Creation and Empowerment of the European Parliament”. Journal of Common Market Studies, vol. 41, no 2, pp. 203-225. 
SCARROW, Susan. (1997), "Political Career Paths and the European Parliament". Legislative Studies Quarterly, vol. 22, n 2, pp. 253-263.

SM - Secretaría del Mercosur. (2004), Un Foco para el Proceso de Integración Regional. Primer Informe Semestral de la Secretaría del Mercosur. Montevidéu, Secretaría del Mercosur.

VAZQUEZ, Mariana. (2001), La Comisión Parlamentaria Conjunta del Mercosur. Reflexiones sobre su Trayectoria Político-Institucional. Trabalho apresentado no 2001 Meeting of the Latin American Studies Association. Washington D. C., 6-8 de setembro.

VIEIRA POSADA, Edgar. (2000), "Perspectivas de la Integración: El Rol de los Parlamentos Regionales", in A. Delgado, R. Rodríguez e M. Alvarez (eds.), El Poder Legislativo en la Democracia y la Integración Andina. Bogotá, UPD/OEA/Universidad Javeriana.

Sites dos Parlamentos Regionais:

Comissão Parlamentar Conjunta do Mercosul:

$<$ http://www.cpcmercosur.gov.ar>.

Parlamento Andino: <http://www.parlamentoandino.org>.

Parlamento Centro-Americano:

$<$ http://www.parlacen.org.gt/principal.asp $>$.

Parlamento Europeu: <http://www.europarl.eu.int $>$.

Parlamento Latino-Americano: <http://www.parlatino.org.br>.

União Parlamentar Internacional:

$<$ http://www.ipu.org/english/home.htm>. 


\section{Resumo}

\section{Parlamentos Supranacionais na Europa e na América Latina: Entre o Fortalecimento e a Irrelevância}

Nenhum processo de integração regional está isento de críticas sobre o seu alegado déficit democrático e/ou institucional. A razão destes déficits é, freqüentemente, apontada como uma conseqüência da escassa accountability e da falta de transparência dos sistemas de decisão em nível regional. Os diferentes blocos regionais têm tentado responder a um ou ambos dos déficits em causa, mediante uma variedade de métodos e opções institucionais. A mais visível das fórmulas aplicadas é a criação e fortalecimento de um Parlamento regional - ou seja, supranacional. Este artigo pretende analisar, comparativamente, cinco Parlamentos regionais na Europa e na América Latina - o Parlamento Europeu, o Parlamento Latino-Americano, o Parlamento Centro-Americano, o Parlamento Andino e a Comissão Parlamentar Conjunta do Mercosul - com o objetivo de compreender o impacto que estas instituições têm tido no âmbito da representação regional, dos processos de decisão e do fortalecimento da accountability. As conclusões sugerem cinco fatores que os autores consideram pertinentes para a explicação das diferenças verificadas entre as duas regiões transatlânticas.

Palavras-chave: Parlamentos Supranacionais - Integração Regional Integração Latino-Americana - Integração Européia

\section{Abstract}

\section{Regional Parliaments in Europe and Latin America: Between Empowerment and Irrelevance}

Virtually no process of regional integration has been safe from the criticism of allegedly suffering from either democratic deficit, institutional deficit or both. These deficits, the argument goes, are the consequence of scarce accountability and the lack of transparency in regional decision-making. Different regional blocs have attempted in a variety of ways to confront one or both of these deficits, the most visible of which is the creation and 
empowerment of a regional parliament. This paper presents a comparative analysis of five of these institutions in Europe and Latin America - i.e. the European Parliament, the Latin American Parliament, the Central American Parliament, the Andean Parliament, and the Joint Parliamentary Commission of Mercosur - with the aim of understanding their impact on regional representation, decision-making and accountability. The conclusions pinpoint five plausible factors in accounting for the differences found across the Atlantic divide.

Key words: Supranational Parliaments - Regional Integration - Latin American Integration - European Integration 